DOI: $10.21802 /$ artm.2020.1.13.194.

УДК 611.351.019:599.731.1]:616.351-002.1

\title{
ПОРІВНЯЛЬНА МОРФОЛОГІЯ ПРЯМОЇ КИШКИ ЛЮДИНИ ТА СВИНІ У НОРМІ
}

\author{
В.І. Талько ${ }^{1}$, І.В. Керечанин ${ }^{2}$, Р.О. Плахотний ${ }^{3}$
}

Приватний вищий навчальний заклад «Київський медичний університет», кафедра анатомії, топографічної анатомії та оперативної хірургії, м. Київ, Україна,

${ }^{1}$ ORCID ID: 0000-0001-7275-7422,

${ }^{2}$ ORCID ID: 0000-0001-3262-2027,

e-mail:dr.kerechanyn@kmu.edu.ua,

${ }^{3}$ ORCID ID: 0000-0001-6858-7387

Резюме. Знання структурної організації прямої кишки є фундаментом для розуміння етіології, клініки захворювання, техніки проведення діагностичних маніпуляцій, вибору методу лікування, у тому числі оперативного втручання.

У статті проведена ревізія попередніх та сучасних наукових робіт, що містять історію терміну «пряма кишка», опис топографії прямої кишки людини, вікові та гендерні особливості її будови і меж; визначені структурні елементи, що забезпечують нормальний пасаж вмісту; описана теорія акту дефекації. На основі літературних даних розглянуто етіологію патологічних станів, таких як закреп, інконтиненція та енкопрез, а також непухлинних захворювань, зокрема парапроктиту.

Оприлюднені сучасні дослідження провідних медичних центрів Європи, США та Японії засвідчують успіхи у галузі вивчення ксенотрансплантації, відтворенні механізму хвороб людини на молекулярному рівні, таких як м'язова дистрофія Дюшена і муковісцидоз. Дослідження відбуваються з використанням свині в якості біомоделі, оскільки ці тварини анатомічно та фізіологічно більш схожі на людей, особливо це стосується серцево-судинної, імунної, дихальної систем, скелетних м'язів, метаболізму тощо; також свині як біологічна модель активно використовуються для розробки й апробації нових медичних технологій.

Перспективи майбутнього дослідження полягають у визначенні придатності свині як біомоделі проктологічних захворювань з подальшим використанням у клінічних експериментах задля розробки нових методів лікування патології прямої кишки у людини.

Ключові слова: проктологія, інконтененція, парапроктит, біомодель.

Вступ. За останнє десятиліття досягнуто суттєвого прогресу в лікуванні захворювань прямої кишки за рахунок використання сучасних методик, зменшилась частота гнійно-запальних ускладнень, анальної інконтиненції та рецидивів. Незважаючи на сучасні досягнення в хірургічному лікуванні патології прямої кишки, залишається досить висока частота незадовільних результатів лікування, такі як: рецидиви нориць прямої кишки спостерігаються у 5,2-40,2 \% хворих, у 13-20 \% відмічаються гнійно-запальні ускладнення, у 19-23 \% хворих відмічається анальна інконтиненція $[1,2]$. Такі дані свідчать про потребу ревізії даних щодо структури прямої кишки та вдосконалення біологічної моделі з метою розробки нових підходів у лікуванні прямої кишки. На сьогодні лабораторні щурі є традиційною моделлю експериментальних досліджень. Але, 3 огляду на розмір прямої кишки, процесу дефекації лабораторні щурі не $є$ зручними для навчального процесу та формування практичних хірургічних навичок, а також для проведення маніпуляцій, особливо хірургічних, задля розробки новітніх підходів у лікуванні та профілактиці захворювань прямої кишки.

У зв'язку з цим актуальним завданням є дослідження поширеності використання свині як біомоделі різних захворювань та використання цієї тварини у медичній галузі загалом.
Структурна організація прямої кишки людини. Знання структурної організації прямої кишки є фундаментом для розуміння етіології, клініки захворювання, техніки проведення діагностичних маніпуляцій, вибору методу лікування, у тому числі оперативного втручання $[1,2]$. Пряма кишка міститься в порожнині малого тазу, розташовуючись на задній його стінці, утвореною крижовою кісткою, куприком та заднім відділом м'язів тазового дна. Апоневроз Денонвільє, або очеревинно-промежинний апоневроз, являє собою перегородку, розміщену у фронтальній площині, натягнуту від дна очеревини до дна порожнини таза, поділяє підочеревинний відділ малого таза на передній відділ, де у чоловіків розміщуються заочеревинний відділ сечового міхура, передміхурова залоза, сім'яні пухирці, ампули сім'явиносних проток і тазових відділів сечоводів. У жінок - сечовий міхур, тазовий відділ сечоводів, шийка матки і більша частина піхви. У задньому відділі й у чоловіків, й у жінок проходить пряма кишка. Таким чином, пряма кишка має статеві топографічні відмінності. Саме тому, з метою ретельного обстеження хворих з патологією прямої кишки, лікар має приділяти увагу не лише термінальному відділу травного тракту, а й суміжним органам, а саме органам малого тазу $[2,3]$. Анатомічною ділянкою переходу сигмоподібної ободової кишки в пряму є пере- 
хід стрічок сигмоподібної ободової кишки у суцільний поздовжній м'язовий шар, тобто перебудова та зміна напрямку гілок верхньої прямокишкової артерії на кишковій стінці. За даними інших літературних джерел [4] пряма кишка починається на рівні верхнього краю третього крижового хребця, тобто місця закінчення брижі сигмоподібної кишки. Інші автори [5] вважають, що втрата сигмоподібною ободовою кишкою своєї брижі $є$ межею переходу надампулярної частини прямої кишки в ампулярну, тобто початок розширення просвіту кишкової трубки (ампула прямої кишки), а не ознакою ректосигмоїдного переходу. Клініцисти верхню межу прямої кишки визначають під час ректороманоскопії по "хаустоновій заслінці". Анатомічно на цьому рівні зникає брижа сигмоподібної ободової кишки, а поздовжній м'язовий шар рівномірно розподіляється навколо прямої кишки [3, 4].

У прямій кишці розрізняють відділи: надампуляний відділ, ампулу прямої кишки й відхідниковий (анальний) канал. Надампулярна частина прямої кишки спереду та з боків прилягає до петель тонкої кишки. Позаду розміщуються крижова кістка та грушоподібний м'яз, який покривається фасцією. Між фасцією та стінкою кишки розміщується крижове сплетення. У сучасній науковій літературі вказуються лише ампула як найбільш розширена частина, що розташована в порожнині малого таза, та відхідниковий канал як нижня частина, що розміщена під тазовою діафрагмою й що закінчується отворомвідхідником [4, 6]. Довжина прямої кишки за даним різних авторів складає від 12 до 20 см, що залежить від розташуванням меж вимірювання, якщо верхньою межею точки вимірювання є мис крижової кістки, то вказано довжину 20 см. Клініцисти вважають, що для практичних цілей зручніше розділяти пряму кишку на п'ять відділів та початковою точкою вимірювання враховують відхідниково-шкірну лінію: надампулярний (або ректосігмовидний) відділ 315 до 18 см, верхньоампулярний відділ (від 12 до 15 см), середньоампулярний відділ (з 7-12 см від заднього проходу), нижньоампулярний відділ (до 6 см від заднього проходу) та промежинний відділ - задній прохід (довжиною від 1,5 до 4 см) $[4,5]$. Діаметр змінюється залежно від частини; так, діаметр надампулярної частини становить 4 см, ампули - 7 см, діаметр анального каналу - 3-6 см та має вигляд щілини на рівні заднього проходу. Ряд зарубіжних авторів розглядають анальний канал та власне пряму кишку (ампулу) як окремі частини термінального відділу травного тракту зі спільною функцією (накопичення та виведення калових мас), спираючись на те, що в ембріогенезі пряма кишка та анальний канал є похідними різних зародкових листків [6]. Так тазовий відділ прямої кишки до рівня верхньої третини анального канала, що відповідає рівню розташування заднєпрохідних заслінок, розвивається $з$ ентодерми задньої кишки, клоаки (епітелій) та оточуючої мезенхіми інші шари стінок, у тому числі внутрішній замикач та повздовжній м'яз. Стінки нижньої частини каналу формуються 3 ектодерми анальної бухти (епітелій) та 3 мезенхіми цієї ділянки. 3 результатів досліджень вважають, що утворення зачатків внутрішнього та зовнішнього сфінктерів відбувається послідовно, першим з'являється зачаток внутрішнього сфінктера на 6-му тижні внутрішньоутробного розвитку з мезенхімних клітин, що розташовані навколо. Дефінітивною межею між ними є відхідниково-прямокишкова лінія, що розташована приблизно на 2 см вище анального отвору та відповідає відхідниковопрямокишковому з'єднанню. Різниця у походженні проявляється також у особливостях кровопостачання, інервації, венозного та лімфовідтоках [2, 3]. Саме тому в зарубіжних сучасних виданнях використовується термін «аноректум» та описується ряд непухлинних захворювань, таких як анокуприковий больовий синдром, прокталгія, кокцигодинія, які характерізуються наявністю болю (єдиний клінічний прояв) у ділянці куприка (кокцигодинія), у задньому проході і в прямій кишці, особливо у спокої, поза дефекацією, ночами [7].

Довжина анатомічного відхідникового каналу становить приблизно 2 см - від відхідниковошкірної лінії до відхідниково-ректальної (зубчастої) лінії з боку порожнини прямої кишки. Хірургічний відхідниковий канал включає не тільки анатомічний канал, верхньою межею якого $є$ аноректальна лінія, але і дистальну частину прямої кишки - до верхнього краю м'язового кільця (внутрішній і зовнішній замикачі), що чітко визначається проктологом під час пальцевого обстеження. Відхідниковий прохід може розташовуватися глибоко, бути воронкоподібним при добре розвинених сідничних м'язах, або плоским, що пояснюється розслабленням м'язів промежини (після пологів, у похилому віці тощо). Опущення промежини $є$ причиною нетримання газів, калових мас, сечі, тобто інконтиненції. 3 клінічної точки зору розрізняють наступні три згини: перший згин, крижовий, спрямований дозаду і відповідає ввігнутості крижової кістки. Другий згин, промежинний, спрямований наперед і відповідає переходу ампули у відхідниковий канал. Описані вигини відбуваються в сагітальній площині. У фронтальній площині пряма кишка вигинається наліво, тому при ставленні клізми хворого кладуть на лівий бік. Вигини враховуються також при проведенні ректоскопії, адже крижовий вигин розташований на глибині 12-15 сантиметрів від ануса [4, 7].

Стінка прямої кишки представлена слизовою оболонкою, підслизовою основою, м'язовою оболонкою та зовнішньою серозною оболонкою, або ж адвентицією. На слизовій оболонці тазової частини прямої кишки візуалізуються 2-3 поперечні півколові складки (plicae transversae recti), складки Нелятона та численні непостійні складки. Слизова оболонка у ділянці відхідникового каналу утворює 8-10 відхідникових повздовжніх складок, стовпи Морганьї (columnae anales), що з'єднані у верхніх відділах відхідникового каналу півмісяцевими складками, заслінки Морганьї, заглибини між ними мають назву відхідникових пазух (sinus anales), пазухи Морганьї, що відіграють важливу роль в утриманні газів та калу [4, $5,7]$. На дні відхідникових пазух залягають анальні залози - крипти, які можуть бути травмовані унаслі- 
док закрепів або ж проносів. За умов приєднання інфекції виникає запалення парапроктит. При парапроктиті в одній із крипт, здебільшого у задній, відшукують точкоподібний отвір, через який просвіт кишки сполучається 3 порожниною абсцесу. Морганьї заслінки утворюють кільцеподібної форми аноректальну лінію, що також відома за старою Базельскою анатомічною номенклатурою як гребінчаста лінія. Нижче заслінок Морганьї розташований гребінець, у ділянці якого слизова тісно зв'язана 3 м'язовим шаром, а саме внутрішнім замикачем. По верхній межі гребінця проходить відхідниково-шкірна лінія, нижче якої розташована “шкірна стрічка" білого кольору, біла лінія або лінія Хілтона шириною 0,5-0,7 см, що не містить сальних, потових залоз та волосся та поступово переходить у пігментовану періанальну шкіру 3 радіарно локалізованими навколо ануса складками [2, $4,6]$.

Слизова оболонка прямої кишки складається з епітелія, власної та м'язових пластинок. Пряма кишка у верхній частині вкрита одношаровим кубічним епітелієм. Кишковий тип епітелію поступово заміщується на шкірний тип, так у стовбчастій зоні відхідникового каналу епітелій багатошаровий кубічний, що заміщується у перехідній зоні на багатошаровий плоский епітелій, а відхідниково-шкірна лінія вкрита багатошаровим плоским зроговілим епітелієм. В епітелії прямої кишки зустрічаються стовпчасті епітеліоцити, келихоподібні екзокриноцити та ендокринні (ентерохромафіноподібні ECL-) клітини. Лімфоепітеліальні вузлики слизової, утворені шляхом міграції лімфоцитів з капілярів, є свідченням генетично детермінованого забезпечення імунного гомеостазу товстої кишки людини та першими реагують на запалення $[4,7,8]$. Шкіра періанальної області пігментована i зморшкувата, містить звичайні залозисті елементи шкіри і періанальні залози (екзокринні та апокринні, в секреті останніх виявляють феромони). Власна пластинка слизової бере участь у формуванні складок прямої кишки та містить поодинокі лімфоїдні вузлики та судини, протоки залоз, розташованих у підслизовій основі. У ділянці стовпчастої зони визначаються сітка тонкостінних кровоносних лакун, кров з яких відтікає в гемороїдальні вени. М'язова пластинка слизової оболонки складається $з$ двох шарів: внутрішнього, утвореного циркулярно розташованими міоцитами, та суцільного зовнішнього шару. У підслизовому прошарку прямої кишки, утвореного пухкою сполучною тканиною, розташоване венозне сплетення, так зване внутрішнє (підслизове) гемороїдальне. При порушенні тонуса стінок цих судин виникає варикозне розширення вен, що може ускладнюватися запаленням та кровотечею. У підслизовій основі стовпчастої зони прямої кишки розташовані 6-8 розгалужених трубчастих залоз, так звані анальні залози (gll. anales), що тягнуться до циркулярного шару м'язової оболонки, перфорують іiі та сліпо закінчуються у міжм'язовій сполучній тканині. Анальні залози є гомологами анальних залоз тварин. За патологічних умов, а саме гострому парапроктиті, протоки цих залоз є основою для формування гнійного ходу, 3 подальшим формуванням абсцесу, черезсфінктерних параректальних нориць [5, 6, 8].
Підслизова основа прямокишкової стінки складається 3 пухкої волокнистої неоформленої тканини, що дозволяє легко відшарувати слизову оболонку від м'язової. У таких випадках інфекція розповсюджується по міжтканинних щілинах, лімфо- і гематогенним шляхом. У підслизовому шарі утворюються гнійнички, які відшаровують слизову оболонку. Гній проникає також в ішіоректальні, пельвіоректальні, підшкірні, параректальні, клітковинні простори, що містять інтрамуральні судинні та нервові сплетення $[9,10]$.

М'язова оболонка прямої кишки складається 3 повздовжнього шару та циркулярного, при чому в ділянці промежинного вигину на рівні білої лінії циркулярні гладенькі м'язові волокна потовщуються (близько 6 мм) та утворюють внутрішній замикач (m. sphicter ani internus), якому виділяється основна участь в утриманні калу. Внутрішній замикач (сфінктер) складається 3 щільних шарів гладких косих та циркулярно розташованих м'язів. Дистально цей замикач закінчується на рівні з'єднання поверхневого і підшкірного шарів зовнішнього замикача заднього проходу. Проксимальна частина цього замикача переходить в циркулярний м'язовий шар прямої кишки. У дистальну частину замикача можуть вплітатися волокна поздовжнього м'язового шару. Ці волокна можуть також вплітатися в зовнішній замикач заднього проходу і з'єднуватися з шкірою заднього проходу. Внутрішній замикач прямої кишки зазвичай тонший у жінок, ніж у чоловіків, і стає більш товстим 3 віком, синхронно проходить втрата тонусу. Він також може потовщуватись при деяких захворюваннях (закреп) [8, 9, 11, 12].

Зовнішній замикач (m. sphicter ani externus) складається 3 поперечно-посмугованої мускулатури, товщиною 2,5-5 см. Він поширюється нижче внутрішнього, фіксуючись до шкіри анального отвору. Взаєморозташування внутрішнього, який частиною волокон переплітається з волокнами зовнішнього замикача, та зовнішнього замикачів нагадує висувні телескопічні трубки. Зовнішній сфінктер описаний як єдиний м'яз, що межує з лобково-прямокишковим м'язом. Також, за даними інших джерел, описаний як двокомпонентна модель, у якій глибока та поверхнева частини сфінктера відхідникового проходу відповідають лобково-прямокишковій та глибокій частині зовнішнього сфінктера заднього проходу. У працях таких вчених як E.T. Milligan, C.N. Morgan зовнішній сфінктер описаний як трикомпонентна модель, що складається $з$ глибокої, поверхневої та підшкірної частин, у якому перша та остання утворюють м'язові кільця, а поверхнева спрямована від сухожилкового центру тазу до куприка [12]. У своїх працях В.А. Wood надає глибокій частині сфінктера та пуборектальному м'язу основну «затульну» роль у регуляції акту дефекації (compressor recti) [2, 12, 13]. Доведено, що саме втрата тонусу або ж пошкодження лобковопрямокишкового м'язу призводить до стійкої інконтиненції та енкопрезу, що проявляється нетриманням сечі та газів, калу $[7,13,14]$.

Пасаж калових мас, накопичення та їх евакуація є багатокомпонентним та включає діяльність не лише зовнішнього та внутрішніх замикачів, м'яза, що 
піднімають задній прохід, але й діяльність таких сфінктерів як колосигмоїдний сфінктер Балі, сигморектальний сфінктер О’Бернара-Пирогова-Мутье. Дослідження A. Shafik 1975-1999 років продемонстрували регуляцію надходження калових мас 3 низхідної ободової кишки у сигмоподібну кишку фізіологічним колосигмоподібним сфінктером довжиною 2,1+\-0,9 см, в основі якого є потовщення циркулярних волокон $[8,15]$. Дослідники визначили реакцію вказаного сфінктера шляхом роздування повітряного балона у низхідній кишці, що призводило до розслаблення колосигмоїдного замикача, та - навпаки - його скорочення при збільшені об'єму балона та підвищення тиску у сигмоподібній кишці. При анестезії колосигмоїдного замикача реакція на розтягнення не спостерігалась. A. Shafik назвав даний процес колосигмоїдним рефлексом. Швидкому пасажу вмісту сигмоподібної кишки у пряму перешкоджає ретосигмоїдний рефлекс, в основі якого лежить розслаблення ректосигмоїдного сфінктера, утвореного широкою циркулярною складкою слизової оболонки по всій внутрішній окружності кишки та потовщенням 2,8+\-0,9 см циркулярних волокон м'язової оболонки у місці переходу сигмоподібної кишки у пряму при підвищені тиску та розтягненні сигмоподібної кишки. При анестезії колосигмоїдного замикача або ж ректосигмоїдного замикача реакція на розтягнення не спостерігалась. Пряма кишка, активно беручи участь в евакуації кишкового вмісту, виконує одночасно і резервуарну функцію. Утримання кишкового вмісту забезпечують всі численні компоненти, які координують роботу затульного апарату прямої кишки, до складу якого входять не тільки м'язовий компонент, але й сенсорна і моторна діяльність анального каналу і шкіри періанальної області, прямої і сигмоподібної кишки [10, 15]. Завдяки сучасним методам обстеження, таким як спіральна комп'ютерна томографія 3 віртуальною колоноскопією, встановлено, що у нормі кут між прямою кишкою та верхньою частиною анального каналу, аноректальний кут, становить 60-100. Збільшення цього кута призводить до енкопрезу (нетримання газів та калу). За допомогою сучасної методики обстеження, а саме спіральної комп'ютерної томографії та віртуальної колоноскопії, доведено, що у хворих на енкопрез дітей аноректальний кут був збільшений, розташований нижче пубококцігіальної лінії, відхідниковий канал значно вкорочений, було зафіксовано стійке розширення просвіту прямої кишки, що свідчить про патологічні зміни структури сфінктерного апарату. Трете потовщення колових м'язових волокон, розміщене на відстані 10 см від відхідника m. sphicter tertius, - м'яз О’БейрноваГепнера (несвідомий стискач). В експерименті з циркулярним пересіченням м'язової оболонки на межі між прямою кишкою та анальним каналом, а також після селективної руйнації внутрішньом'язового нервового сплетення ректоанальний рефлекс зникає, тобто рухова активність прямої кишки знаходиться під контролем автономної інервації $[8,14,15]$.

Свині як біомодель у медичних експериментальних дослідженнях. Незважаючи на величезні успіхи біомедичних досліджень, попит на покра- щення моделей хвороб людини зростає. Це особливо актуально для хвороб, де моделі гризунів не відображають фенотип людського захворювання. У порівнянні з гризунами, свині як біомодель анатомічно та фізіологічно більш схожі на людей, особливо це стосується серцево-судинної, імунної, дихальної систем, скелетних м'язів, метаболізму тощо. Важливо відзначити, що на сучасному етапі стали доступні ефективні та точні методики генної інженерії свиней, що полегшує створення індивідуальних моделей тварин, що імітують механізми хвороб людини на молекулярному рівні, таких як м'язова дистрофія Дюшенна, кістозний фіброз. Особлива увага приділяється потенційним перевагам використання цих моделей для тестування ефективності та безпеки методів лікування у генній інженерії, таких як «ехоn skipping», наприклад, Clustered Regularly Interspaced Short Palindromic Repeats (CRISPR)/CRISPR-associated system [8, 16].

Вчені провідних медичних університетів Японії та США прагнуть покращити добробут експериментальних тварин, дотримуючись принципу адекватного підбору біомоделей, перш ніж перейти до клінічних випробувань. У центрі розвитку передових медичних технологій вважається, що як свійські, так і генетично модифіковані свині будуть ідеальними преклінічними експериментальними тваринами модельних систем. Свиня як біологічна модель активно використовується у дослідженнях медичної галузі, а саме у медичних технологіях (інструментарій, апаратура тощо), терапії та ксенотрансплантації. У свиней як біомоделей були створені генетично модифіковані моделі кістозного фіброзу, що, на відміну від моделей миші, більш схожі на людський кістозний фіброз. У науковому дослідженні описані відповідні результати та детально описані бронхоскопічні процедури для легені свиней, що є суттєвим внеском клінічну практику пульмонологів [17, 18].

У 2015 році на базі Національного інституту біоресурсів і природокористування сучасними вченими проведено операцію $з$ метою закриття артеріального протоку, а саме імплантація окклюдера $3 \beta$ цирконієвого сплаву 5-місячним поросятам. Вчені відмітили, що анатомічно та фізіологічно структура організму свиней схожа. Незважаючи на особливості ендоваскулярної імплантації приладів у судинне русло тварин, свиня повністю придатна як біомодель серцево-судинних захворювань [19].

Завдяки роботам Thomas E. Starzl, [16] ксенотрансплантація 3 використанням органів свині може вирішити значне збільшення дефіциту органів для алотрансплантації. В останні два десятиліття основний прогрес був досягнутий у генній інженерії та розумінні ксеноімунної біології свиней. У Японії Center for Development of Advanced Medical Technology, Jichi Medical University ta Center for Experimental Medicine, Jichi Medical University вже понад 10 років використовує свиней як біомодель для моделювання хвороб людини, при розробці та розвитку нових пристроїв та терапевтичних стратегій [17]. Студенти-медики набувають хірургічних навичок, молоді вчені працюють над інновацією інструментів 
для ендо- та лапараскопічних маніпуляцій, проводяться наукові дослідження з стовбуровими клітинами, трансплантації органів [16, 17, 18].

Сьогодні вже ні в кого не викликає сумніву той факт, що певні органи підходять для трансплантації людині від генномодифікованих свиней, про що свідчать досліди провідних медичних інститутів. Дослідники [17] успішно видалили Pervs 3 генома свині, використовуючи техніку редагування гена CRISPR-Cas9, яка дозволила їм вирощувати свиней, позбавлених вірусів. Це, у свою чергу, усуває одну з найбільших перешкод для трансплантації органів від свиней до людини.

У 2015 році на Конгресі Товариства клітинної трансплантації за участі Міжнародної асоціації трансплантації острівців підшлункової залози та Міжнародної асоціації ксенотрансплантації (Cell Transplant Society, International Pancreas and Islet Transplant Association, and International Xenotransplantation Association) було обговорено попередні досягнення у ксенотрансплантації острівців підшлункової залози свиней та прогрес у трансплантації інкапсульованих острівців хворим на цукровий діабет 1-го типу з нестабільним перебігом захворюванням. Наразі вчені зосередженні на подальшій розробці заходів у боротьбі з цукровим діабетом, а саме: генетичній модифікації свиней, спрямованій викликати більшу секрецію інсуліну острівців та/або зменшити імунну реакцію на трансплантовані інкапсульовані острівці, вдосконалення структури самої капсули 3 метою зменшення запальної реакції на структурні елементи капсули. Також ксенотрансплантація острівців підшлункової залози потребує вдосконалення нормативно-правової бази [21].

У лабораторії генного центру (Laboratory for Functional Genome Analysis (Lafuga), Gene Center, Lmu Munich, Germany) експериментальним шляхом вченими успішно генетично модифіковано м'язову дистрофію Дюшенна у свиней, тобто мутацію у гені білка дистрофіна, що призводить до порушення актино-міозинового комплексу та характеризується масивними структурними та функціональними змінами скелетних м'язів. Біопсія двоголового м'яза стегна тварин 2-го дня життя та 3-х місячних тварин демонструвала прогресуюче зниження рівня білків віментіну, нестіну. Ступінь зміни у м'язах помітно зросла 3 віком тварин, відображаючи прогресування патологічних змін та знижені функціональної м'язової тканини. Дослідження довело, що для подальших клінічних випробувань у якості біомоделі свиня як лабораторна тварина підходить більше, ніж щурі $[18,21]$.

Завдяки науковому дослідженню Elisabeth KemTer (Lehrstuhl für Molekulare Tierzucht und Biotechnologie, LMU München, Germany) відкрито нові перспективи для наноформування функціональних людських нирок. Захворювання нирок $є$ серйозною проблемою у всьому світі, і число пацієнтів 3 хронічними захворюваннями нирок та гострою або хронічною нирковою недостатністю зростає щороку. Гемодіаліз і перитонеальний діаліз застосовують для заміни детоксикаційної функції нирок у пацієнтів 3 нирковою хворобою. Хоча ці процедури зберігаються, вони пов'язані з вираженим порушенням якості життя і не можуть замінити важливі функції нирок, такі як ендокринна діяльність (продукція реніну, еритропоетину, активація вітаміну D) та регулювання електролітів/гомеостазу води. Трансплантація нирки поки що єдиний варіант відновлення всіх аспектів нормальної ниркової функції, забезпечуючи набагато кращу якість життя і більше виживання, порівняно 3 діалізом. Однак існує серйозний брак донорських органів людини $[16,20]$. До сучасних стратегій відносять: ксенотрансплантацію нирок 3 генетично модифікованих донорських свиней, використання екстракорпоральних біоштучних нирок, вирощених у порожнистих волокнопристроях, а також нано-нирковою генерацією 3 стовбурових клітин і ембріональних тканин-попередників. Зважаючи на складність архітектури та особливість численних вузькоспеціалізованих та диференційованих типів клітин, нирки $\epsilon$ одним 3 найскладніших органів. Одним 3 підходів $є$ направлена поетапна диференціація клітин стовбурових ембріональних або індукованих плюрипотентних стовбурових клітин 3 використанням специфічних чинників росту та дрібних хімічних інгібіторів конкретних сигнальних шляхів у ниркових клітинпопередників, які за відповідних умов можуть утворювати складні трубчасті та клубочові структури. Формування органу може бути досягнуто шляхом ін'єкції стовбурових клітин, генетично спрямованих для формування конкретної тканини або органу на ранніх стадіях розвитку ембріону. Вчені трансплантували метанефрос 30-ти денних ембріонів свиней у сальник свиней-реципієнтів. Прищеплені метанефроси досягли розмірів 5-7 мм на третій тиждень експерименту та 3 см на 8-му тижні. У структурі пересадженого органу виявлено чітке формування нефронів та збірних канальців. У щурів такі експерименти закінчуються гідронефрозом за рахунок атрофії тканини. Це дослідження має ряд важливих наслідків для майбутніх спроб вирощування нанонирки та ксенотрансплантації та подолати дефіцит донорських органів [20, 22].

В Інституті фізіології тварин (Institute of Animal Physiology, Department of Veterinary Sciences, LMU Munich, Munich, Germany) шляхом експерименту в трансгенних свиней INS C94Y успішно розробили стабільний фенотип діабетичної і очної зміни, такі як катаракта. Метою дослідження було проведення поглибленого аналізу патологічних змін у сітківці INS C94Y свиней, які піддавалися гіперглікемії упродовж років, що представляє собою хронічний діабетичний стан. Діабетична ретинопатія $є$ серйозним ускладненням цукрового діабету, що часто призводить до сліпоти. Оскільки патофізіологія діабетичної ретинопатії неповністю зрозуміла і нові лікувальні заходи вимагають тестування, виникає потреба в надійних моделях тварин, що імітують всі ускладнення діабетичної ретинопатії. Свинячі очі поділяють важливу анатомічну та фізіологічну схожість 3 людськими очима. За допомогою гістологічних та імуногістохімічних методів було проаналізовано очі шести модулів С94Y свиней, отриманні ураження порівнювалися $з$ характеристиками патології, тобто людської діабетичної ретинопатії, таких як внутрішньосудинні аномалії, симптоми проліферативної діабетичної 
ретинопатії, набряку сітківки в регіоні. Науковці дійшли висновку, що INS C94Y трансгенномодифіковані свині $є$ цікавою моделлю для вивчення патофізіології діабетичної ретинопатії та для тестування нових терапевтичних стратегій [22, 23].

Висновки. Існує значна потреба у проведенні подальших досліджень, спрямованих на порівняння структурної організації прямої кишки людини та свині і визначення придатності цієї тварини як експериментальної з подальшим використанням у клінічних дослідженнях задля розробки нових методів лікування патології прямої кишки у людини.

\section{References:}

1. Zakharash MP, Baliczkij VV, Kurik AG. Sovremennye khirurgicheskie tekhnologii $\mathrm{v}$ lechenii paczientov s sochetannoj patologiej analnogo kanala i pryamoj kishki. Klinicheskaya khirurgiya. 2018; Noyab, 22; 85(11):22-5.

2. Clark SJ. Benign anal disease. JAAPA. Available from: 2016; Nov, 29(11):23-29. Available from: https://www.ncbi.nlm.nih.gov/pubmed/27749400 doi: 10.1097/01.JAA.0000502857.05728.98. PubMed Central PMID: 27749400.

3. Potemyn SN. Khronycheskyi medlenno tranzytornyi kolonostaz: mekhanyzmy razvytyia y vozmozhnosty khyrurhycheskoho lechenyia. Nauchnoe obozrenye. Medytsynskye nauky. 2016; 6:84-103. URL: https://science-medicine.ru/ru/article/viewid=948.

4. Rao SS, Bharucha AE, Chiarioni G, Felt-Bersma R, Knowles C, Malcolm A, Wald A. Functional Anorectal Disorders. Gastroenterology. 2016; Mar, 25. pii: S0016-5085(16)00175-X. doi: 10.1053/j.gastro.2016.02.009. PMID: 27144630; PMCID:PMC5035713.

5. Narayanan SP, Bharucha AE. A Practical Guide to Biofeedback Therapy for Pelvic Floor Disorders. Curr Gastroenterol Rep. 2019; Apr, 23;21(5):21. doi: 10.1007/s11894-019-0688-3. Available from: https://www.ncbi.nlm.nih.gov/pubmed/31016468. PMID: 31016468

6. Pratt T, Mishra K. Evaluation and management of defecatory dysfunction in women. Curr Opin Obstet Gynecol. 2018; Dec, 30(6):451-457. Available from: https://www.ncbi.nlm.nih.gov/pubmed/30247166 doi: 10.1097/GCO.0000000000000495. PMID: 30247166.

7. Eickmeyer SM. Anatomy and Physiology of the Pelvic Floor Phys Med Rehabil Clin N Am. 2017; Aug, 28(3):455-460. doi: 10.1016/j.pmr.2017.03.003. Epub 2017 May 27. PMID: 28676358.

8. Pykov MY, Shaplov DS, Dzhavatkhanova RY, Demyna AM. Luchevaia dyahnostyka pry khronycheskykh zaporakh u detei. Medytsynskyi sovet. $2017 ; 1: 186-192$.

9. Klin B, Efrati Y, Berkovitch M, Abu-Kishk I. Anal fissure in children: a 10-year clinical experience with nifedipine gel with lidocaine. Minerva Pediatr. 2016; Jun, 68(3):196-200. Epub 2014 Nov 20. Available from: https://www.ncbi.nlm.nih.gov/pubmed/ 25411941.

10. Amy E. Foxx Orenstein, Sarah B. Umar, Michael D. Crowell. Common Anorectal Disorders. Gastroenterol Hepatol (NY). 2014; May, 10(5):294-301. Available from: https://www.ncbi.nlm.nih.gov/ pmc/articles /PMC4076876/. PMID: 24987313; PMCID: PMC4076876.

11. Forootan M, Darvishi M. Solitary rectal ulcer syndrome: A systematic review. Medicine (Baltimore). 2018; May, 97(18):e0565. doi: 10.1097/MD. 0000000000010565. PMID: 29718850; PMCID: PMC6392642.

12. Wright WF. Infectious Diseases Perspective of Anorectal Abscess and Fistula-in-ano Disease. Am J Med Sci. 2016; Apr, 351(4):427-34. Available from: https://www.ncbi.nlm.nih.gov/pubmed/27079352 doi: 10.1016/j.amjms.2015.11.012. PMID: 27079352.

13. Wu XR, Liu XL, Katz S, Shen B. Pathogenesis, diagnosis, and management of ulcerative proctitis, chronic radiation proctopathy, and diversion proctitis. Inflamm Bowel Dis. 2015; Mar, 21(3):703-15. Available from: https://www.ncbi.nlm.nih.gov/ pubmed/25687266 doi: 10.1097/MIB.000000000 0000227 . PMID: 25687266.

14. Jennifer SB, Shashidharan M. Anal Fissure Clin Colon Rectal Surg. 2016; Mar, 29(1): 30-37 Available from: https://www.ncbi.nlm.nih.gov/pmc/articles/ PMC4755763/ doi: 10.1055/s-0035-1570390. PMID: 26929749; PMCID: PMC4755763.

15. Amgad E. Salem, Elham A. Mohamed, Hosam M. Elghadban, Galal M. Abdelghani. Potential combination topical therapy of anal fissure: development, evaluation, and clinical study. Drug Deliv. 2018; 25(1): 1672-1682. Epub 2018 Nov 15. Available from: https://www.ncbi.nlm.nih.gov/pmc/articles/ PMC6237160/doi: 10.1080/10717544.2018.1507059. PMID: 30430875; PMCID: PMC6237160.

16. Blutke A, Renner S, Flenkenthaler F, Backman M, Haesner S, Kemter E, and al. The Munich MIDY Pig Biobank - a unique resource for studying organ crosstalk in diabetes. Mol Metab. 2017; Aug, 6(8):931-940. doi:10.1016/j.molmet.2017.06.004. EPub 2017; Jun, 13. PMCID: PMC5518720; PMID:28752056.

17. Kurome M, Leuchs S, Kessler B, Kemter E, Jemiller EM, Foerster B, and al. Direct introduction of gene constructs into the pronucleus-like structure of cloned embryos: a new strategy for the generation of genetically modified pigs. Transgenic research. 2017; 26(2):309-318. doi: 10.1007/s11248-016-0004-z. Epub 2016 Dec, 10. PMID: 27943082

18. Frohlich T, Kemter E, Flenkenthaler F, Klymiuk N, Otte KA, Blutke A, and al. Progressive muscle proteome changes in a clinically relevant pig model of Duchenne muscular dystrophy. Scientific reports. 2016; 6:33362. doi:10.1038/srep33362.

19. Panychkyn YuV, Skyba IA, Zakharova VP, Beshliaha VM, Solomon VV, Ruzhyn YuA, ta in. Osobennosty metodyky provedenyia doklynycheskoho eksperymenta po ymplantatsyy okkliudera yz $\beta$ tsyrkonyevoho splava na svyniakh kak byolohycheskoi modely. Sertse i sudyny. 2015; 4:2530.

20. Kemter E, Wolf E. Pigs pave a way to de novo formation of functional human kidneys. Proc Natl Acad Sci U S A. 2015; Oct, 20; 112(42):12905-12906. 
doi:10.1073/pnas.1517582112. EPub 2015; Oct, 12. PMCID:PMC4620893; PMID:26460047.

21. Cooper DK, Matsumoto S, Abalovich A, Itoh $\mathrm{T}$, Mourad NI, Gianello PR, and al. Progress in clinical encapsulated islet xenotransplantation. Transplantation. 2016; 100:2301-2308. DOI:10.1097/TP. 0000000000001371 PubMed Center PMID: 27482959; PMCID: PMC5077652.

22. Bongoni AK, Kiermeir D, Schnider J, Jenni H, Garimella P, Bahr A, and al. Transgenic expression of human CD46 on porcine endothelium: effect on coagulation and fibrinolytic cascades during ex vivo human-to-pig limb xenoperfusions. Transplantation. 2015, Oct, 99(10):2061-9. doi: 10.1097/TP.0000000000000746. PubMed Central PMID: 25965410.

23. Kleinwort KJH, Amann B, Hauck SM, Hirmer S, Blutke A, Renner S, and al. Retinopathy with central oedema in an INS C94Y transgenic pig model of long-term diabetes. Diabetologia. 2017; 60(8):15411549. Epub 2017; May, 8. doi:10.1007/s00125-0174290-7. PMID: 28480495.

\section{УДК 611.351.019:599.731.1]:616.351-002.1 \\ СРАВНИТЕЛЬНАЯ МОРФОЛОГИЯ ПРЯМОЙ КИШКИ ЧЕЛОВЕКА И СВИНЬИ В НОРМЕ}

\author{
В.И. Талько ${ }^{1}$, И.В. Керечанин ${ }^{2}$, Р.А. Плахотный ${ }^{3}$
}

Частное выстее учебное заведение «Киевский медииинский университет», кафедра анатомии, топографической анатомии и оперативной хирургии, г. Киев, Украина,

${ }^{1}$ ORCID ID: 0000-0001-7275-7422,

${ }^{2}$ ORCID ID: 0000-0001-3262-2027,

e-mail:dr.kerechanyn@kmu.edu.ua,

${ }^{3}$ ORCID ID: 0000-0001-6858-7387

Резюме. Знание структурной организации прямой кишки является основой для понимания этиологии, клиники болезни, методов диагностических манипуляций, выбора метода лечения, в том числе оперативного вмешательства.

В статье анализируются предыдущие и современные научные работы морфологов и клиницистов: описаны топография прямой кишки, структура, возрастные и гендерные различия. Также описаны различия точки зрения морфологов и клиницистов относительно термина "прямая кишка", границы, а также структурные элементы, которые обеспечивают нормальное прохождение содержимого кишечника и акт дефекации. На основе литературных данных рассматривается этиология патологических состояний, таких как запор, недержание и энкопрез, этиология неопухолевых заболеваний, таких как парапроктит.

Результаты современных экспериментов ведущих медицинских учреждений Европы, США и Японии свидетельствуют об успехах исследований в области ксенотрансплантации, воссоздании механизмов заболеваний человека на молекулярном уровне, таких как мышечная дистрофия Дюшена, муковис- цидоз с использованием свиньи как биомодели. Свинья в качестве биомодели анатомически и физиологически больше похожа на человека, особенно это касается сердечно-сосудистой, иммунной, дыхательной систем, скелетной мускулатури, метаболизма и т.д. Свинья как биологическая модель активно используется в исследованиях медицинской промышленности, а именно в медицинских технологиях (инструменты, аппарат и т.д.).

Перспективой будущих исследований является определение пригодности свиней как биомодели с последующим использованием в клинических испытаниях для разработки новых методов лечения ректальной патологии у людей.

Ключевые слова: проктология, инконтененция, парапроктит, биомодель.

\section{UDC 611.351.019:599.731.1]:616.351-002.1 \\ COMPERATIVE MORPHOLOGY OF HUMAN'S RECTUM AND A PIG IN NORM}

\section{V.I. Talko ${ }^{1}$, I.V. Kerechanyn ${ }^{2}$, R.O. Plakhotnyi ${ }^{3}$}

Private higher educational establishment «Kyiv medical university", Department of anatomy, topographical anatomy and operative surgery, Kyiv, Ukraine,

${ }^{I}$ ORCID ID: 0000-0001-7275-7422,

${ }^{2}$ ORCID ID: 0000-0001-3262-2027,

e-mail:dr.kerechanyn@kmu.edu.ua,

${ }^{3}$ ORCID ID: 0000-0001-6858-7387

Abstract. Knowledge of the structural organization of the rectum is the foundation for understanding the etiology, mechanism of action of the disease, techniques for diagnostic manipulations, methods of treatment, including operative intervention. The article analyzes the postulates and revise the previous and current scientific works of morphologists and clinicians. The topography of the rectum is described, its correlation with adjacent bodies, structure, age and gender differences.

Due to the modern methods such as virtual spiral colonoscopy, the colorectal and rectosigmoid reflexes have been studied. The role of these components of anal sphincter mechanism and the physiology of defecation have been described.

The etiology of pathological conditions such as constipation is taken into account and can occur because of changes in the pelvic diaphragm. An increase in the anorectal angle, insufficiency of sphincter apparatus leads to incontinence and enkopresis. The article describes the opinions of morphologists and clinicians regarding the term "rectum", its's structure and boundaries.

Paraproctitis occurs due to structural injury of the rectal wall, such as crypts, lymphoid nodules of the submucosa, etc. These lymphatic nodes react and respond to inflammation. In case of abscesses formation, the submucosa can easily be separated from the other layers and this promotes the spreading of infection to adjacent tissues and organs; perirectal spaces and be complicated by the formation of fistulas. One type of fistula is 
transsphincteral which is a consequence of spreading inflammation along the course of anal glands.

Pigs, in recent times is more common as a biomodel in Vivo Testing. However, despite the enormous success of biomedical researches, the demand has increased for new and improved biomodels representing human diseases. This is especially true in case of diseases where a rat's model does not reflect the phenotype of a human disease. In comparison to rats, pigs are more anatomically and physiologically similar to humans to be used as a biomodel, especially when considering cardiovascular system, the immune system, the respiratory system, skeletal muscles, metabolism, etc.

It is emminent to note that the effective and accurate methods of genetic engineering of pigs become benignant, when facilitating the creation of individual animal biomodels that mimic the mechanism of human diseases at a molecular level, such as muscular dystrophy
Duchenna, cystic fibrosis. Modern experiments of famous medical institutions in Europe, the USA and Japan demonstrate achievements in the field of xenotransplantation, creating methods to grow organs capable of human transplantation.

This appears to be beneficial to patients with chronic renal insufficiency, diabetes, etc. The pig as a biological model is actively used in various medical industry researches, namely medical technologies (instruments, apparatus etc.). Suitability of swine and its uses are worthy prospects in upcoming medical researches; with subsequent use in clinical research for creating various new methods and applications in approaching the treatment of rectal pathology in humans.

Keywords: proctology, incontinence, paraproctitis, biomodel.

Стаття надійшла в редакцію 28.02.2020 p. 